\title{
INTERESSES DIFUSOS QUESTÕES SOBRE A EFETIVIDADE DE SUA TUTELA*
}

\author{
DIFFUSE INTEREST QUESTIONS ON THE \\ EFFECTIVENESS OF ITS GUARDIANSHIP
}

\author{
Nilson Tadeu Reis Campos Silva* \\ Luiz Fernando Belinetti"
}

\begin{abstract}
Resumo: Analisa e compara o tratamento dado pelo ordenamento jurídico aos interesses difusos nas ações individuais e nas ações coletivas, sublinhando as diferenças conceituais essenciais a partir do redesenho do conceito clássico de lide e as razóes dessas diferenças. Fornece uma visão sistêmica das normas brasileiras sobre tutela coletiva e crítica da jurisdição envolvendo interesses difusos, coletivos e individuais homogêneos. Examina os pontos fortes e fracos da organização política da sociedade no estágio atual sob o prisma das Organizações Não-governamentais e seu papel na defesa dos interesses metaindividuais. Conclui pela necessidade de se obter efetividade às decisões judiciais através de ruptura de paradigmas sobre a neutralidade do juiz e da participação da sociedade organizada a partir da reformulação de conceitos processuais clássicos vinculados à conflituosidade e do controle por meio de divulgação.
\end{abstract}

Palavras-chave: Processo Civil, Tutela Coletiva, Jurisdição, Ação Civil Pública, Lide, Interesses Difusos, Sentença, coisa Julgada, Organização não-governamental, Efetividade.

Abstract: Evaluates and compares the treatment by the legal system of common rights in individual and class action lawsuits which underly the essential conceptual differences based on the

\footnotetext{
Artigo extraído da Dissertação de Mestrado, apresentada ao Programa de PósGraduação Stricto Sensu da Universidade Estadual de Londrina, de autoria do primeiro sob a orientação do segundo.

* Mestre em Direito Negocial pela Universidade Estadual de Londrina em 2004.

**** Doutor em Direito pela Pontifícia Universidade Católica de São Paulo e coordenador do Mestrado em Direito Negocial da Universidade Estadual de Londrina.
} 
Nilson Tadeu Reis Campos Silva; Luiz Fernando Belinetti

re-evaluation of the classic litigious concept and the reasons for these differences. Provides a systemic vision of the Brasilian standards concerning collective tutelage and critique of the jurisidiction regarding common rights, collective and homogeneous individuals. Analyzes weak and strong political organizational issues of the society in the and their role in defense of the community interests by not-for-profit organizations. Concludes for the necessity to obtain effective judicial decision through the rupture of the paradigms concerning the neutrality of judges and the participation of the organized community in reformulating the classic legal process concepts linked to the conflict of legal rights and the control by the information dissemination by the media.

Key words: Civil Process, Colective Guardianship, Jurisdiction, Class Action Lawsuit, Litigious, Diffuse Interests, Sentence, Return Sentence, Not-for-profits, Effectivity.

A peregrinação do Homem pela Terra é marcada, desde os primórdios, pela busca da satisfação de necessidades, sejam elas fisiológicas ou não, e matizada pelas nuances impactantes que derivam dos interesses manifestados nessa persecução.

Neste sentido, Carnelutti já anotou: "O fenômeno corrente da vida revela que os homens, em meio à sua existência, possuem múltiplas necessidades, inspiradas pelas mais diferentes razões. E que para satisfação de tais necessidades existem os bens” (1936, p. 33).

Por isso, parece ser fundamental uma exata compreensão da funcionalidade dessas reações e desses comportamentos.

É mister que se conheça qual ou quais as forças motrizes que impulsionam, retardam ou alavancam os seres humanos, porque é a partir da apreensão desse conhecimento que poderemos tracejar uma axiologia que legitime ou sustente um sentido universal dos interesses difusos a serem tutelados e a aptidão ou não de provimento jurisdicional para protegê-los ou satisfazê-los.

Necessária, a propósito, uma revisitação à Escala de Maslow (1954) e à sua análise piramidal acerca das necessidades básicas do Homem: hierarquizada a partir da base, ter-se-iam as necessidades fisiológicas; de segurança, de amor e afeição; de estima; até chegar-se às necessidades de auto-realização.

Dentre as necessidades fisiológicas, como fez Maslow (1908-1970), dever-se-ia considerar, por igual hierarquizadas, as vitais, pertinentes a 
prover o organismo de oxigênio, água, até de defesas às intempéries climáticas como deflagradoras das sensações de frio e calor.

Já as necessidades de segurança priorizam as de estabilidade, segurança e proteção, enquanto que as necessidades que dizem respeito ao amor e afeição se dividem de modo escalonado na busca da satisfação de anseio de integração grupal, fuga da solidão e de carinho.

Por outro lado, as necessidades de estima são as fundadas nas de auto-estima, dignidade e de reconhecimento, passando pelas de busca de atenção e independência, e encimadas pela de confiança.

E, por fim, o topo da pirâmide de Maslow escalona as necessidades de auto-realização, que são aquelas que visam prover o desejo de atingir todo o potencial, da busca da beleza e da verdade, e o desejo de Justiça.

Agora, revistas as necessidades básicas do ser humano, deve-se voltar sob este prisma à perquirição da definição de interesse, para se entender como torná-lo concreto e efetivo, eis que umbilicado à reação e ao comportamento individual.

Assim, tem-se que o vocábulo interesse traduz uma relação de reciprocidade entre um indivíduo e um objeto que corresponde (ou que corresponda) à determinada necessidade daquele.

Por isso que

a razão entre o homem e os bens, ora maior, ora menor, é o que se chama interesse. Assim, aquilata-se o interesse da posição do homem em relação ao bem, variável conforme suas necessidades. Donde consistir o interesse na posição favorável à satisfação de uma necessidade (SANTOS, 1990, p. 3-4).

É o caso, por exemplo, da conexão genérica que se estabelece entre uma anunciada exposição de artes e um indivíduo que esteja priorizando uma necessidade de auto-realização, visando suprir carência de beleza plástica: o cenário da exposição lhe proporciona esta visagem e, ao mesmo tempo (daí a reciprocidade), sua visita supre os anseios de compartilhar as obras junto ao público.

Nesse contexto, interesse de fato pode ser definido também como uma relação, porém de necessidade e não de reciprocidade, que um indivíduo tenha em relação a determinado bem ou valor da vida (CARNELUTTI, 1936, p. 13). 
Prosseguindo com o mesmo exemplo, com o fito de se verticalizar a análise, sob o viés do interesse de fato ter-se-ia o interesse do mesmo amante de artes despertado pela obra ou conjunto de obras de um determinado artista, que o induz a adquirir para si essa obra com o desiderato de desfrutá-la permanentemente.

Aprofundando-se um pouco mais a definição, chega-se ao interesse jurídico, aqui entendido como a relevância de ordem material ou instrumental conferida pelo direito positivo a determinadas situações.

No mesmo exemplo desenhado, o direito positivo ao disciplinar a aquisição de uma obra, definindo e delimitando a relação entre o bem e o indivíduo, estaria, a rigor, disciplinando o interesse de fato.

$\mathrm{Da}$ incidência desse regramento eclode a possibilidade de uma situação conflituosa, posto que as necessidades são infindas enquanto que os bens ou valores da vida capazes de satisfazê-las são finitos: o indivíduo superará essa conflituosidade priorizando este bem em detrimento de outro, conforme o tônus de sua necessidade, resolvendo o conflito segundo a intensidade de seu interesse neste ou naquele bem e a hierarquização da sua satisfação.

Sucede, porém, que se, mais de um indivíduo manifestar interesse pelo mesmo bem e nele persistir, o conflito intersubjetivo que se estabelecerá, ainda que potencialmente apenas, não será passível de solução tão simplista como a apontada.

É neste passo que surge o chamado interesse processual, dando gênese a uma necessidade específica para o indivíduo: a do exercício do direito subjetivo processual de ação, ou o interesse de agir em juízo.

Essa busca da atividade jurisdicional, por seu turno, faz brotar uma necessidade que não se restringe à esfera do indivíduo. Antes, a extrapola, açambarcando as esferas de todos os indivíduos.

Pode-se mesmo afirmar que essa nova necessidade pertence ao Estado, focada na efetividade da jurisdição: “[...] a premissa sociológica de todo ordenamento jurídico é, pois, o interesse coletivo à composição dos conflitos individuais" (BUZAID, 1956, p. 92).

É que, ao avocar para si o exercício da tutela jurisdicional, o Estado visou satisfazer a sua necessidade de implantar e manter a pacificação social, realizando esse interesse de modo não apenas eficiente e eficaz, mas efetivo. 
De se indagar, então, em quê consiste efetivamente interesse, além do já exposto?

Duas são as posições doutrinárias acerca do tema: a dos que defendem uma concepção subjetiva e a dos que postulam pela procedência de uma construção objetiva para conceituá-lo.

Segundo a concepção subjetivista, interesse é vislumbrado em seu caráter interno, eis que tem como centro a pessoa. Ou seja, considerase uma relação entre pessoas para a satisfação de uma necessidade humana. Assim, o interesse estaria relacionado com tudo aquilo sobre o qual incide necessidade e desejo.

Daí Ihering ter afirmado: "o direito subjetivo é um interesse juridicamente protegido" (apud NADER, 1990, p. 376), tendo intrínseca na definição a existência de uma pessoa.

Já na concepção objetiva, pugnada dentre outros por Carnelutti (1936, p. 11), interesse é a posição favorável para a satisfação de uma necessidade, definição que não se situa no âmbito no âmbito volitivo da pessoa mas sim entre o ente que experimenta esta necessidade e aquele que pode satisfazê-la.

Nesta perspectiva, se faz presente uma relação de complementaridade, graças a utilidade específica de um ente para outro ente: um pode complementar o outro, material ou imaterialmente, tanto no presente quanto no futuro.

Daí a importância da objetividade contida na tese defendida por Carnelutti (1936), eis que retira a idéia da presença obrigatória da pessoa, porque nem todos os bens podem ser classificados como interessantes à pessoa, enfatizando dessarte a concepção relacional.

A correção da postura que vê o interesse sempre como uma relação provém da racionalidade lógica: os bens podem ser materiais ou imateriais, prescindindo às vezes de existência concreta ou material, e não deixando de existir por se circunscreverem à realidade intangível ou ideal.

É, assim, a utilidade específica de um ente para com o outro que é determinante do interesse.

Viu-se que interesse individual é o interesse particular de um sujeito de direito, que ocorre quando o mesmo ente satisfaz mais de uma necessidade.

E o interesse coletivo? A doutrina cogita classificá-lo em três espécies: 
interesse coletivo stricto sensu, interesse difuso e interesse individual homogêneo. $\mathrm{O}$ interesse coletivo lato sensu engloba essas três espécies de interesses mencionadas.

Impende destacar que a noção de interesse coletivo tampouco é unívoca, podendo ser entendida primeiro como aquela que diz respeito ao interesse pessoal de um determinado grupo de pessoas componentes de uma pessoa jurídica, visto então como uma universalidade de pessoas e não de bens.

Sob este prisma, interesse coletivo é o interesse dos componentes da pessoa jurídica, dos sócios ou acionistas ou associados. Contudo, esse interesse, em última análise, traduz o que seria o interesse individual de um sujeito de direito que é a pessoa jurídica, sendo, por isso inadequada tal definição para se compreender o interesse subjacente às ações coletivas.

Por outro viés, pode-se conceber interesse coletivo como o que diz respeito a vários interesses individuais agrupados, isto é, o somatório de interesses individuais de um grupo de pessoas. Em essência, também aqui se tem uma ótica inapropriada de interesse coletivo para o presente desiderato, pois o interesse é individual, em litisconsórcio.

Por derradeiro, pode-se entender interesse coletivo como a síntese de interesses individuais de um grupo de pessoas, posto que tal induz à idéia de uma utilidade indivisa, ainda que não necessariamente indivisível (BELINETTI, 2003). Sob esta perspectiva, a rigor o interesse é uno acerca de uma utilidade que possa ser ao mesmo tempo compartilhada por todas as pessoas do grupo.

É, assim, o interesse coletivo aquele que atende a todo um grupo de uma maneira não cindida: o interesse de cada um do grupo, individualmente considerado, desaparece, passando a ter relevância apenas o interesse grupal, tal qual sucede com a idéia de bem comum. Esta, a acepção mais adequada a idealização de ações coletivas, e que se utiliza neste escorço.

Os interesses coletivos, considerados lato sensu, devem ser situados topicamente, ou seja, contextualizados segundo a época, eis que suscetíveis de pertinência às gerações passadas, presentes e futuras.

Neste passo, adota-se aqui a definição de Belinetti (2003) que vê o interesse coletivo como "síntese de interesses individuais", ou seja,

${ }^{1} \mathrm{O}$ termo "síntese" aqui, tem o estrito sentido hegeliano, até para diferenciar do somatório de interesses individuais que existe, por exemplo, em um litisconsórcio. 
"uma utilidade indivisa (não necessariamente indivisível) que pode ser ao mesmo tempo compartilhada por todos os membros do grupo".

Por isso que, no contraponto, por exemplo, do direito de propriedade em face do interesse pela segurança pública, a preservação deste último, supra-individual, prevalecerá.

Assim definido o interesse coletivo, impende clarificar, ainda que en passant (vez que sua análise aprofundada refoge ao âmbito deste trabalho) suas espécies, de resto definidas pelo Código de Defesa do Consumidor, em seu art. 81: interesses difusos, coletivos e interesses individuais homogêneos.

Segundo o legislador, difusos são os interesses "transindividuais, de natureza indivisível e de que sejam titulares pessoas indeterminadas e ligadas por circunstâncias de fato”.

Interesses coletivos, na dicção legal, são "os transindividuais de natureza indivisível, de que seja titular grupo, categoria ou classe de pessoas ligadas entre si ou com a parte contrária por uma relação jurídica base". O legislador define ainda os interesses individuais homogêneos como "os decorrentes de origem comum".

$O$ aspecto da indivisibilidade do bem jurídico é que, prevalentemente, exige e autoriza uma solução única, por parte do Estado-juiz.

É que a indivisibilidade demonstra que a mesma ofensa (não necessariamente um único agravo, mas visualizada de forma global) prejudica a todos os interessados.

Nesta seara, abra-se aqui um parêntesis para sublinhar o posicionamento de Belinetti, discrepante dos demais doutrinadores, no sentido de não serem os interesses individuais homogêneos indivisíveis, mas sim interesses divisíveis "que o ordenamento permite serem tratados coletivamente, como uma utilidade indivisa" (2003, p. 147).

E é desse permissivo do direito posto, aliado à compreensão da noção de interesse coletivo, que autoriza situá-lo, com suas três espécies declinadas, em uma categoria específica, como um tertium genius.

Guido Alpa minudencia a dupla face dos interesses difusos, bem como sua distinção enquanto nova espécie de interesses 
suscetíveis de tutela, ao tracejar a análise de suas características genéticas, essencial para sua compreensão conceitual²:

O interesse difuso tem uma dupla roupagem: subjetiva e objetiva. Subjetivamente, é um interesse pertinente ao indivíduo, enquanto este se reveste de uma qualificação particular, ou seja considerado em uma dimensão particular, atrelado ao seu status: por ex. de consumidor, de poupador (econômico, que economiza), usuário (consumidor) do ambiente, usuário dos serviços públicos, etc. Objetivamente, expressa-se e só pode ter sua essência captada com referência a um grupo, a uma categoria (de consumidor, poupador, usuário do ambiente, etc.)

Isso é certamente um interesse pertencente ao indivíduo, com relação a cada grupo, coletividade, num sentido amplo, "formação social", preserva-se individual mas é composto de indivisibilidade, enquanto é objeto de consideração e portanto, de proteção jurídica, visto que é referente ao indivíduo; todavia, e aqui está exatamente (de fato) a sua particularidade, se capta somente na competência (atribuição) do indivíduo a um grupo, visto que, o interesse difuso é considerado como uma unidade, não determinada, nem definida a priori, e que aparece excessivamente sufocada e frágil.

Belinetti, por seu turno, após lembrar que se identifica o interesse público primário com o da coletividade como um todo, e que o interesse público secundário é o modo como a Administração

\footnotetext{
${ }^{2}$ Interessi Diffusi, RePro 81/146-147. No original: "L'interesse diffuso ha uma doppia veste: soggettiva e oggettiva. Soggettivamente, è um interesse che pertiene all'individuo, in quanto questi rivesta uma particolare qualificazione o sia considerato in una particolare dimensione, attinente al suo status: ad es. di consumatore, di risparmatiore, di fruitore dell'ambiente, di utente di servizi pubblici, ecc. Oggettivamente, si esprime e se ne può cogliere l'essenza, solo com riferimento ad un gruppo, ad una categoria (di consumatori, risparmiatori, utenti, fruitori dell'ambiente, ecc.) Esso è certamente un interesse che pertiene all'individuo, in quanto ogni gruppo, collettività, in senso ampio "formazione sociale" riguarda individui, è composta da individui, in quanto è oggetto di considerazione e quindi di protezione giuridica perché riferito ad individui; tuttavia, e qui sta appunto la sua particolarità, si coglie solo nell'apartenenza dell'individuo ad um gruppo, perché, esso se considerato come uma monade, non determinata, né definibile a priori, appare troppo sufocato e debole."
} 
Pública vê o interesse público, nomina os interesses difusos, bem como os coletivos e os individuais homogêneos, como

irmãos consangüíneos do interesse público primário, já que não há como promovê-lo sem o respeito aqueles interesses. Na verdade, a diferença entre eles é que o interesse público primário é visto sob a perspectiva do Estado, ao passo que os interesses coletivos lato sensu são vistos sob a perspectiva da sociedade e dos grupos sociais (1997, p. 165).

Assim, nem são os interesses difusos propriamente interesses públicos, tampouco são interesses privados, mas, sim, inerentes à comunidade em geral, por isso que supra ou metaindividuais.

Por outro lado, a utilização indiscriminada do vocábulo "direito" como sinônimo de "interesse", refere-se à visão individualista do Direito que vê direito subjetivo do grupo com o correlato dever jurídico.

E essa concepção se reporta à idéia clássica da relação jurídica polarizada entre o sujeito ativo titular do direito e o sujeito passivo titular do dever.

Embora a discussão sobre qual seria a terminologia correta na seara do coletivo, se direito ou se interesse, esteja ultrapassada na doutrina e tenha relevo apenas acadêmico, mercê de o legislador brasileiro usar indistintamente ambas as expressões, como realce até da adoção de uma noção de relação jurídico-processual diferenciada que refoge aos estreitos limites da visão individualista, utiliza-se aqui apenas o vocábulo interesse coletivo a ser tutelado.

É que, em se tratando de interesses coletivos, não há como identificar facilmente o titular do direito, mas apenas quem pode defender o interesse indiviso do grupo, e que necessariamente não é quem irá se aproveitar do resultado.

Daí se vislumbrar a questão sob a ótica da relação de complementaridade o interesse coletivo objetivamente considerado, ou seja, na medida em que satisfaz a síntese da necessidade de todos os entes, beneficiando ao grupo, merecendo por isso tutela específica.

Advirta-se, porém que, assim como ontologicamente inexiste distinção entre os dois termos, as conseqüências da tutela jurisdicional serão sempre as mesmas, seja para uma situação de "interesse" protegida juridicamente, ou de "direito" por igual tutelado. 
A origem da tutela dos interesses difusos remonta ao Direito Romano, em que já se diferenciavam os interesses públicos primários (res publicae) dos secundários (res extra nostrum patrionimum).

No ordenamento jurídico brasileiro, a gênese dessa proteção verificou-se em decorrência da necessidade de proteção à organização social e da mantença da paz social, com a ação popular regulada pela Lei $\mathrm{n}^{\circ}$. 4.717/65, com aspectos penais e civis, inicialmente voltada à defesa do patrimônio público apenas.

Contudo, a legislação processual civil brasileira, concebida sob a perspectiva individualista, sempre foi o grande óbice à proteção adequada de interesses que pertençam indistintamente a todos os indivíduos, porque sempre se exigiu a confusão da figura do titular do interesse individual, com a do legitimado para a propositura da ação: "Ninguém poderá pleitear, em nome próprio, direito alheio, salvo quando autorizado por lei” (art. $6^{\circ}$. do Código de Processo Civil).

Por isso, o advento da Lei n ${ }^{\circ}$. 7.347/85, instituindo a Lei da Ação Civil Pública para tutelar interesses transindividuais, focada no meio ambiente, consumidor, bens e direitos e valor artístico, estético, histórico, turístico e paisagístico, foi como a inserção de um corpo estranho em um ordenamento jurídico inspirado na visão individualista, até porque vigente a concepção da relação jurídicoprocessual de caráter personalista.

Como os interesses tutelados naquela norma transcendem à esfera do indivíduo, existindo uma pluralidade de pessoas que são as titulares dos interesses em litígio, a exigência da confusão do titular do interesse individual com o legitimado para a propositura da ação, postulado básico do Código de Processo Civil, mostrou-se insuficiente para solucionar a questão da legitimação ativa da Lei da Ação Civil Pública: nesta, há legitimação ordinária, concorrente e disjuntiva, autônoma, da chamada parte ideológica, que, ao invés de simplesmente representar outrem que seja o alegado titular do direito material, substitui a coletividade.

Apenas com a Constituição Federal de 1988, reconhecendo a existência de interesses coletivos lato sensu ao cuidar da legitimação ativa para sua defesa (art. $5^{\circ}$., XXI e LCXX; art. $8^{\circ}$., III; art. 129, III; e art. 232), é que o caráter de excepcionalidade da Lei da Ação Civil 
Pública deixou de ferir a coerência do sistema jurídico brasileiro aprisionado ao antropocentrismo e que, por isso, não admitia se não por exceção um processo coletivizado, assim entendido, especialmente aqui, o voltado à defesa dos interesses difusos.

Com a edição da Lei $n^{\circ}$. 7.078/90 - Código de Defesa do Consumidor, vigente a Lei da Ação Civil Pública, formou-se um microsistema de proteção jurídica aos interesses coletivos lato sensu, a interagir com o regramento do Código de Processo Civil que, ainda hoje, deve ser ajustado às especificidades das situações coletivizadas.

Esse microsistema, formatado pela Lei da Ação Civil Pública e pelo Código de Defesa do Consumidor, engloba, hoje, diversos diplomas legais, dentre os quais se destacam: Lei ${ }^{\circ}$. 7.853/89 (disciplina a proteção das pessoas portadoras de deficiência); Lei $\mathrm{n}^{\circ}$. 7.913/89 (Lei de Defesa dos Investidores do Mercado de Valores Mobiliários); Lei $n^{\circ}$. 8.069/89 (Estatuto da Criança e do Adolescente); Lei n ${ }^{\circ}$. 8.429/ 92 (Lei da Improbidade Administrativa); Lei $n^{\circ}$. 8.884/94 (Lei Antitruste); Lei $\mathrm{n}^{\circ}$. 8.974/95 (disciplina normas de segurança e fiscalização na engenharia genética); Lei $\mathrm{n}^{\circ}$. 9.868/99 (Lei da Ação Direta de Constitucionalidade); Lei n ${ }^{\circ}$. 9.882/99 (Lei de argüição de descumprimento de preceito fundamental); Lei ${ }^{\circ}$. 10.257/01 (Estatuto da Cidade); Lei n ${ }^{\circ}$. 10.741/03 (Estatuto do Idoso), além de uma miríade de normas protetivas do meio ambiente.

Ancorado em base constitucional desde 1988, o sistema jurídicoprocessual brasileiro da defesa dos interesses coletivos lato sensu contempla, ainda, poucas quebras do paradigma individualista que norteia o Código de Processo Civil, dentre elas o reconhecimento, pelo art. $1^{\circ}$. da Lei Antritruste, de que a coletividade é a titular dos bens jurídicos por ela tutelados.

A eficácia desse microsistema tem sido possibilitada, em grande parte, pela legitimação do Ministério Público ao manejo das ações voltadas à defesa dos interesses difusos, em cumprimento mesmo de sua função institucional preconizada pela Lei Complementar $n^{\circ}$. 40/ 81, Lei Orgânica do Ministério Público, constitucionalizada expressamente pelo inciso III do art. 129 da Constituição Federal de 1988, e atualmente concedida também pela Lei $\mathrm{n}^{\circ}$. 8.625/93, Lei Orgânica Nacional do Ministério Público. 
Se, de um lado, o fato de o Ministério Público ser, mercê da previsão normativa e da alta especialização atingida, exponencial e eficiente autor de ações na tutela dos interesses difusos, de outro a quebra do monopólio dessa legitimação e concorrente outorga à sociedade civil organizada tem se mostrado como solução ideal para se buscar atingir a efetividade nessa proteção.

É que, ao contrário do que sucede com a ação popular, a ação civil pública não pode ser aforada pelo cidadão: o pólo ativo da relação processual é reservado, necessariamente, ao Ministério Público; à União; aos Estados; aos Municípios; às autarquias; às empresas públicas; às fundações; às sociedades de economia mista; ou, ainda, às associações que estejam constituídas há pelo menos um ano, nos termos da lei civil, e que incluam, dentre as suas finalidades institucionais a proteção ao meio ambiente, ao consumidor, à ordem econômica, à livre concorrência, ou ao patrimônio artístico, estético, histórico, turístico e paisagístico ${ }^{3}$.

Mesmo o ingresso como litisconsorte na lide manejada pelo Ministério Público é vedado ao indivíduo: apenas o Poder Público ou as entidades legitimadas nos termos da lei podem ser admitidos como tal na ação civil pública visando a defesa de interesses difusos ${ }^{4}$.

Como se infere do art. $5^{\circ}$. da Lei de Ação Civil Pública, trata-se de legitimação autônoma para a condução do processo.

A ratio da norma que exclui a possibilidade de o indivíduo isoladamente manejar a ação civil pública reside na razoabilidade e na adequação: eventual sucumbência é muito mais danosa para o litigante individual do que para potências econômicas ou pessoas jurídicas.

Ressalte-se que, por óbvio, o fato de ser vedado o ajuizamento da ação civil pública ao indivíduo, não impede o exercício do direito de ação individual quando em jogo interesses situados na esfera jurídica apenas de determinadas pessoas, mormente quando a esfera decisória daquela ação não alcançar interesses individuais específicos.

É importante suscitar aqui, a necessidade de um novo olhar para a questão da legitimatio nas ações civis públicas voltadas à defesa dos

\footnotetext{
${ }^{3}$ art. $5^{\circ}$ da Lei $7.347 / 85$.

${ }^{4}$ Art. $5^{-}$, $\S \S 1^{\underline{a}}, 2^{\underline{a}}, 3^{\underline{a}}$, e $5^{\text {a }}$, da Lei $7.347 / 85$.
} 
interesses difusos: apenas os entes previstos no art. $5^{\circ}$. da Lei 7.347/85 guardam pertinência para esse manejo?

Se for cotejado esse dispositivo do instrumento que é, indubitavelmente, o mais adequado para a tutela dos interesses transindividuais, com o artigo 83 do Código de Defesa do Consumidor, chegar-se-á a uma ampliação ainda não reconhecida pela maioria da doutrina.

Veja-se que o Código de Defesa do Consumidor que, como repetido, configura o sistema jurídico da tutela dos interesses difusos, expande sua área de incidência sem peias: "[...] para a defesa dos direitos e interesses protegidos por este Código são admissíveis todas as espécies de ações capazes de propiciar sua adequada e efetiva tutela"

Para que a Lei da Ação Civil Pública mantenha simetria com essa regra, eis que integra o mesmo sistema jurídico, a ampliação das possibilidades de ser agente ativo de uma ação também deve ser recepcionada, não ficando compartimentalizada às figuras elencadas em seu art. $5^{\circ}$.

Como adverte Baptista da Silva (1997, p. 139),

a capacidade processual de ser parte é mais ampla do que o da capacidade jurídica de direito civil. Assim poderão, eventualmente, responder como autores, ou como réus, certos organismos ou coletividades não personalizadas, tais como as mesas dos corpos legislativos para as ações de mandado de segurança, condomínio, herança jacente, massa falida, consórcio de consumidores etc.

Tem-se, pois, que a personalidade jurídica necessariamente não precisa coincidir com a judiciária, tanto o que legislador atribuiu capacidade especial para estar em juízo a entes despersonalizados ${ }^{6}$.

Daí estar-se autorizado a simpatizar com a tese de Podestá (2002), que, perfilhado a Lamartine Corrêa de Oliveira (2002) e a Cirne Lima (2002), conclui ser a família "ente de inequívoca personalidade judiciária” e, assim, legitimada a ajuizar ação civil pública como ente sponenziale, isto é, como entidade que reúne as condições para tal em função dos interesses tutelados:

\footnotetext{
${ }^{5}$ art. 83.

${ }^{6}$ art. $12, \mathrm{CPC}$
} 
[...] o legislador constitucional, em sintonia com os reclamos da sociedade e baseado na própria principiologia conferida à importância da família, inequivocadamente criou um novo ente legitimado ativo (estabelecer os meios legais que garantam à pessoa e à família a possibilidade de se defenderem), ao lado daqueles já previstos no art. 5o da Lei 7.347/85, para o exercício e defesa dos interesses difusos em juízo com relação à programação televisiva (especialmente), cujos parâmetros são dados pelo art. 221 da CF, sendo perfeitamente sustentável que qualquer ente familiar específico proponha a ação civil alegando a inadequação de determinada e questionada programação com a proposição de seu ajuste aos fins legais.

A eventual dificuldade da identificação de chefe de família com referência à pertinência ativa à possibilidade de outro ramo da mesma família discordar do ajuizamento da ação apenas atesta a intensa litigiosidade como característica dos interesses difusos [...] (PODESTÁ, 2002, p. 171).

É claro que, em termos práticos, a possibilidade de ajuizamento de ação civil pública por família esbarra na incapacidade de o Poder Judiciário absorver tal numerosa demanda, dificultada ainda mais pelo fato de que a família não pode ser reduzida unicamente às uniões formais, admitida ainda a família monoparental.

Essa realidade fática, aliada ao elevadíssimo grau de subjetividade crítica quanto aos interesses difusos em tela, implica em se reconhecer que, se de um lado, a idéia é pertinente e adequada, de outro, arrosta o princípio da razoabilidade e da factibilidade.

Contudo, a maioria da doutrina, em que pese admitir que entes públicos despersonalizados também possam ajuizar ação civil pública, desde que demonstrem estar voltados à tutela dos interesses difusos, não admite a extensividade pretendida pela integração sistemática do artigo 83 do Código de Defesa do Consumidor: "No entanto, é taxativo (numerus clausus) o rol de legitimados previstos no art. 5o da LACP e 82 do CDC, faltando legitimidade ativa ad causam a qualquer outra pessoa natural ou entidade” (MARANHÃO; CAMBI, 2004, p. 103).

A solução deve ser encontrada quebrando-se o paradigma da ótica individualista que aprisiona o interesse processual ao vínculo de uma 
relação jurídica base, como sói ocorrer nas tutelas meramente individuais, pois o autor não busca, na ação civil pública, a tutela de interesse seu, mas sim de interesse que transcende a individualidade.

$\mathrm{O}$ interesse autorizador do manejo da ação que busca a proteção para interesses difusos deve ser aferível em razão da qualidade transcendental desses interesses e de sua pertinência temática.

É correta, pois, a solução que admite, por propiciar adequada e efetiva tutela, como legítima entidade que tenha por finalidade institucional a defesa de interesse difuso.

A natureza transcendental dos interesses tutelados exige que se supere a perspectiva reducionista e se adote outra, holística, e é nesse sentido que os tribunais principiam a dar um temperamento à aparente rigidez normativa.

Por exemplo: o inciso II do art. $5^{\circ}$. elenca as finalidades institucionais que são conditio à legitimação das associações, e nem por isso se pode tê-las como taxativas. E é nessa perspectiva ampliativa que se manifestam doutrinadores e tribunais, como anota NERY JUNIOR (2004, p. 1341): "Deve ser entendida como incluída nesse inciso II, a finalidade de proteção da ordem urbanística, bem protegido judicialmente pela LACP $1^{1}$. III, com a redação que lhe foi dada pelo Ecid [Estatuto da Cidade, Lei 1.025/2001]"

O Superior Tribunal de Justiça também seguiu essa visão nãoreducionista ao julgar a pretensão de moradores voltada a impedir a edificação de cemitério em zona de proteção a mananciais:

A ação civil pública pode ser ajuizada tanto pelas associações exclusivamente constituídas para a defesa do meio ambiente, quanto por aquelas que, formadas por moradores de bairro, visam ao bemestar coletivo, incluída, evidentemente, nessa cláusula a qualidade de vida, só preservada enquanto favorecida pelo meio ambiente (apud NEGRÃO; GOUVEIA, 2003, p. 1070).

Maranhão e Cambi, que divergem da posição aqui defendida, por entenderem que a Lei da Ação Civil Pública estabelece rol taxativo para a legitimação ativa, mencionam outro julgado da mesma Corte em que se reconheceu legitimidade à associação cujos estatutos não estabeleciam como finalidade proteção ambiental: 
Ação civil pública - Legitimidade - Fundação de assistência social à comunidade de pescadores - Defesa do meio ambiente Construção - Fábrica de celulose.

Embora não constando expressamente em suas finalidades institucionais a proteção ao meio ambiente, é a fundação de assistência aos pescadores legitimada a propor ação civil pública para evitar a degradação ao meio em que vive a comunidade por ela assistida (...) (AR 497-BA - 1‥ Seção - rel. Min. Garcia Vieira - j. 12.08.1998 - DJU 22.11.1999, p. 142) (2004, p. 108).

Essa exegese que considera não apenas os fatores endógenos, mas os exógenos do processo, é a que melhor se presta à compreensão da tutela jurisdicional coletiva.

Mesmo a restrição legal imposta pelo art. $5^{\circ}$., I, da Lei da Ação Civil Pública às associações, mediante a qual se exige estarem constituídas há pelo menos um ano, tem sido objeto de temperamento doutrinário:

Prazo ânuo de constituição. O Juiz poderá dispensar esse prazo, pois há casos em que a associação é constituída ex post factum. A dispensa é válida para todas a ações propostas com base na LACP, CDC e ECA, exceto para o mandado de segurança coletivo, pois a exigência da pré-constituição está na CF 5a. LXX, não podendo a lei ordinária dispor diversamente (NERY JUNIOR; NERY, 2003, p. 1341).

Esse entendimento é respaldado pelo $\S 4^{\circ}$. do mesmo art. $5^{\circ}$. da norma sob exame: "O requisito da pré-constituição poderá ser dispensado pelo juiz, quando haja manifesto interesse social evidenciado pela dimensão ou característica do dano, ou pela relevância do bem jurídico a ser protegido".

Impende destacar que a flexibilidade legal tem como mens principal a repercussão social e a transcendência dos interesses envolvidos, em absoluta coerência com a visualização contextualizada, não individual, do tema.

Tem-se, pois, que, para que se alcance uma adequada e efetiva tutela dos interesses difusos, a legitimidade ativa da ação civil pública há de 
ser reconhecida segundo a pertinência temática da lide com a missão do grupamento social, sob a ótica da transcendentalidade dos interesses envolvidos, a ser apreciada caso a caso.

Observe-se que esta conclusão é consentânea à própria definição legal de interesses difusos: "transindividuais, de natureza indivisível e de que sejam titulares pessoas indeterminadas e ligadas por circunstâncias de fato”.

Sob outra ótica, é mister que se ultrapasse o conceito clássico de lide, para vê-la não apenas como conflito intersubjetivo, mas como colisão de interesses individuais ou sociais.

É que a idéia de pretensão resistida para se definir lide parece ser inadequada às relações processuais que envolvam interesses difusos: especialmente na ação civil pública ajuizada para a defesa daqueles interesses, o Estado-Juiz é instado a se pronunciar em função da leniência, e não da existência de lide.

Explica-se: ora o Estado deixa de exigir do cidadão aquilo que deveria exigir em relação a determinado interesse difuso, ora o cidadão deixa de exigir do Estado aquilo que deveria ter exigido. Nas duas situações, há, implícita, a convenção de se deixar a situação fática no estado em que se encontra.

Como essa leniência acomodativa é, por si só, lesiva (ou potencialmente lesiva) ao interesse que, por pertencer a todos, não é disponível para uns, nenhuma pretensão resistida irá ser submetida ao Poder Judiciário.

Ao contrário, será acionado o Estado-Juiz, exatamente, porque não foi configurada a lide (no sentido carnellutiano do termo), ausentes quaisquer antagonismos entre as partes!

Vê-se, pois, que na ação civil pública o autor não espera do réu deixar de resistir à sua vontade, e tampouco espera o autor não ser constrangido pela vontade do réu. Não se cuida, na relação processual, de antagonismos subjetivos.

O autor da ação civil pública busca o Judiciário para fazer cessar uma conflituosidade social, decorrente da contraposição de interesses de diversos grupos dentro da sociedade, e que pertencem, também, a esses mesmos grupos.

$O$ fato de, circunstancialmente, estarem esses interesses contrapostos, podendo ambos serem lícitos e legítimos, aliado à 
transcendentalidade de um deles, é que gera o conflito a exigir a tutela jurisdicional.

Ver a lide como colisão de interesses, individuais ou sociais, auxilia o entendimento de que a titularidade para a defesa de interesses difusos pertence a pessoas indeterminadas, e que a busca da tutela jurisdicional é fundada na repercussão social de eventual risco aos interesses transindivinduais. Por isso que basta que estejam eles institucionalizados genericamente enquanto missão associativa, para que a entidade esteja legitimada ao manejo da ação civil pública.

As organizações não-governamentais são os novos atores no concerto das relações público-privadas, capazes de modificarem a realidade social, através do manejo da ação civil pública, sendo que, no Brasil, existem três espécies: as organizações sociais; as de educação e assistência social sem fins lucrativos; e as organizações da sociedade civil de interesse público, existindo um único marco regulatório específico para o terceiro setor ${ }^{7}$, a Lei $\mathrm{n}^{\circ}$. 9.790/99 que criou a Organização da Sociedade Civil de Interesse Público.

A extrema liberalidade de constituição para essas associações, aliada à ausência de marcos regulatórios eficazes; à escassez de recursos financeiros, à uma certa frouxidão de princípios, tem propiciado a confusão da ética do público e do privado, permitindo-se, em muitos casos, que se desvirtue a vocação das Organizações Não-Governamentais com sua transformação em braço do Estado, quando não em sanguessugas desse mesmo Estado.

Por isso que a pura e simples imputação da legitimatio a grupo social não soluciona a questão, nem do acesso à justiça, nem da efetividade da tutela jurisdicional dos interesses difusos.

A experiência tem demonstrado que a enumeração legal dos legitimados é insuficiente, pois a natureza difusa dos interesses não permite sua compartimentalização rotulada, mais própria da visão mecanicista.

De fato, conceitos difusos como qualidade de vida por exemplo, se prestam a emprestar cariz cinzento à chamada pertinência temáticoinstitucional exigida às associações que, por isso mesmo, é inócua.

\footnotetext{
${ }^{7}$ Entende-se por terceiro setor a sociedade civil organizada. O Estado é o primeiro setor, enquanto que as empresas que objetivam lucro formam o segundo setor.
} 
É mister o apoio estatal para que, à semelhança das empresas que se reestruturaram e assumiram a forma de redes, a chamada sociedade civil possa também se estruturar em forma de rede social para a defesa de interesses difusos em Juízo.

As organizações atuantes em redes, de tamanhos diversos, com desigualdades políticas até, podem otimizar as relações de poder, via de regra assimétricas, através da interdependência propiciada por eficientes canais de comunicação.

Isto permitiria que, antes de se adotar uma decisão, incluída aí decisão política e mesmo a prolação de uma sentença judicial, se considerasse os efeitos dessa decisão sobre o Estado, sobre os diversos segmentos da coletividade, porque aquela decisão afetará, necessariamente, a rede inteira.

Essa, a mentalidade que se faz necessária à tutela efetiva dos interesses difusos, raciocínio que reserva, ao Estado, a função de desobstrução dos vasos comunicantes da rede.

Como visto, a indeterminidade é a característica fundamental dos interesses difusos. Por se situarem em segmento extremamente delicado, de forte conteúdo social, sua defesa exige, primeiro, a inafastabilidade da capacidade postulatória do Ministério Público, dada sua função estatal, e, em segundo, uma postura proativa do Judiciário.

Observe-se que o indivíduo é, historicamente, o elo mais fraco, mais débil, na relação que envolve o poder público, as entidades privadas e os cidadãos. Por isso, a reorganização da sociedade civil em rede deve ser estimulada pelo Estado, e contar com sua efetiva participação.

Para tanto, é exigível um alto grau de conscientização comunitária, eis que é do fato de se tomar consciência de um problema que surge a iniciativa da providência na sua solução: a transcendentalidade dos interesses difusos não só fomenta, como permite e exige forte participação da sociedade civil organizada.

O surgimento das ONGs abriu um novo canal para a sociedade participar da gestão pública: deixou de ser passiva, passando a exercer seus direitos e a praticar a cidadania participativa. Devido à sua profusão, parece ainda não ser do entendimento da população o efetivo papel dessas entidades, merecendo esforços de esclarecimento e de conscientização. 
A concepção finalística da ação civil pública destina-se à proteção da coletividade, titular desses interesses: seu papel na efetividade da tutela jurisdicional adquire expressão maior, por permitir, em uma só ação, quando se trata de lesão potencial ou objetiva a interesses difusos, que se defenda esses interesses que são de vários beneficiários.

As origens das grandes mutações institucionais havidas no Estado podem ser vislumbradas por uma vertente ideológica que critica o Estado neoliberal para ressaltar a incapacidade governamental na condução de projetos de desenvolvimento sócio-econômicos, e também pela vertente pragmática que propõe uma redefinição do tamanho do Estado e do papel do Governo, sob o argumento de que não são atendidas de forma adequada as necessidades básicas da população em termos de segurança, saúde, educação, meio ambiente, etc.

Daí se preconizar que o espírito judicante na tutela dos interesses difusos deva ser alicerçado no tripé necessidade, utilidade e efetividade, a fim de ser adequada a prestação jurisdicional.

Neste cenário, a tutela jurisdicional deve buscar a realização dos objetivos sociais explícitos ou implícitos no ordenamento jurídico, a partir da opção política deduzida na Constituição Federal, o que exige um alargamento da concepção do Poder Judiciário cujas funções passam a ter forte conotação política e de grande impacto social, porque os provimentos jurisdicionais, mais do que nunca, devem estar contextualizados, e não aprisionados ao formalismo dos autos.

Ganha relevo, neste ponto, a ênfase dada ao conteúdo da sentença, posto que, a impossibilidade fática de se determinarem os titulares dos interesses difusos, implica tornar mais ampla ainda a extensão da coisa julgada, cujo regime legal é estabelecido pelos artigos 81 e 103, I, do Código de Defesa do Consumidor.

É que, em sede de interesses difusos, a coisa julgada (que aqui só ocorre nas hipóteses de sentenças que julguem procedente o pedido) vai além da relação fática simplesmente considerada: alcança absolutamente a todos, exatamente porque uma única lesão afetou a todos.

Como no mundo da tutela coletiva, que privilegia um maior acesso à justiça, o universo atingido é consideravelmente superior, é fundamental que as pessoas atingidas pela eficácia da coisa julgada tenham ciência desse fato, seja para saberem que uma ação civil pública 
está em trâmite, seja para tomarem ciência de que seus interesses foram preservados, seja para exercitarem eventuais direitos decorrentes do decisum.

Daí ser insuficiente, se não inócua, a previsão do art. 94 do Código de Defesa do Consumidor para publicação de edital em órgão oficial da notícia do ajuizamento de ação.

Defende-se, assim, que os juízes, ao prolatarem sentenças de procedência em ações coletivas, condenem a parte sucumbente a veicular a decisão, em linguagem acessível e clara, pelo maior número possível de veículos de comunicação, a fim de que o maior número de pessoas possível tome ciência, e que os tribunais e os órgãos administrativos mantenham um canal aberto de comunicação e informação acerca das ações coletivas.

Porque a efetividade da prestação jurisdicional depende, sobretudo, de se disseminar a informação junto ao seu destinatário final, que é a sociedade, tem-se, por outro viés, que a falta de divulgação na gestão dos recursos oriundos de condenações em ação civil pública, por impedir, à coletividade, a fiscalização e o monitoramento dos resultados do provimento jurisdicional na realidade fática, é obstáculo à concreção daquela efetividade.

A nova ambiência social que envolve os interesses difusos deve privilegiar a participação social e permitir o acesso à informação pela coletividade. Por isso se pugna, também, por se tornar obrigatória a disseminação de informações sobre a utilização de recursos obtidos em decorrência de condenação em ação civil pública, através da compulsória divulgação de campanhas publicitárias institucionais nos veículos de comunicação de massa.

Além disso, a formação de uma rede envolvendo entidades públicas e privadas, para permitir a rápida circulação de informações quanto à lesão de interesses difusos, quanto ao ajuizamento e julgamento de ação civil pública, servirá, inclusive, para que as entidades civis funcionem como parceiras do Ministério Público, primeiro dos legitimados à tutela daqueles interesses.

A organização da sociedade para utilização de processos sistêmicos que permitam a difusão de decisões judiciais amoldadas à natureza jurídica dos interesses metaindividuais, aliada à disseminação, pelo Estado, de informações acerca das ações civis públicas, utilizando-se 
dos veículos de comunicação em massa, propiciará obter-se efetividade na tutela jurisdicional dos interesses difusos e facilitará o acesso à Justiça.

\section{REFERÊNCIAS}

BAPTISTA DA SILVA, O. A. Teoria geral do processo civil. São Paulo: Revista dos Tribunais, 1997.

BELINETTI, L. F. Definição de interesses difusos, coletivos em sentido estrito e individuais homogêneos. Palestra. JORNADAS BRASILEIRAS DE DIREITO PROCESSUAL CIVIL, 5. Foz do Iguaçu. 2003.

Mandado de Segurança Coletivo. Perspectiva conceitual e pressupostos de admissibilidade no direito positivo brasileiro. Tese não publicada. Biblioteca da Pontifícia Universidade Católica de São Paulo, 1997.

BRASIL, Judiciário. STJ-2‥ Turma, Resp 31.150-SP, rel. Min. Ari Pargendier, j. 20.5.96, não conheceram, v.u., DJU 10.6.96, p. 20.304. In: NEGRÃO, T.; GOUVÊA, J. R. F., Código de Processo Civil, 36. ed. São Paulo: Saraiva, 2003.

BUZAID, A. Do agravo de petição. 2. ed. n. 41. São Paulo: Saraiva, 1956.

CARNELUTTI, F. Sistema di diritto processuale civile, v. I, p. 33., n. 13. Padova: Cedam, 1936.

MARANHÃO, C.; CAMBI, E. Partes e Terceiros na Ação Civil Pública por dano ambiental. In: DIDIER JR, Fredie e WAMBIER, Teresa Arruda Alvim (coord.) Aspectos polêmicos e atuais sobre os terceiros no processo civil e assuntos afins. São Paulo: Revista dos Tribunais, 2004, p. 103.

MASLOW, A. H. S. Motivation and Personality. Nova York: Harper \& Row, 1954

NADER, P. Introdução ao estudo do direito. São Paulo: Forense, p. 376

NERY JR., N.; NERY, R. M. de A. Código de Processo Civil comentado. 6.. ed., São Paulo: Revista dos Tribunais, nota 14, 2003. 
PODESTÁ, Fábio Henrique. Interesses Difusos, qualidade da comunicação e controle judicial. São Paulo: Revista dos Tribunais, 2002.

SANTOS, M. A. Primeiras linhas de direito processual civil. v. 1. n. 1. 14. ed., São Paulo: Saraiva, 1990. 
